Article

\title{
Development of a Low-Depth Modular GHX through a Real-Scale Experiment
}

\author{
Kwonye Kim ${ }^{1}$, Sangmu Bae ${ }^{1}\left(\mathbb{D}\right.$, Yujin Nam ${ }^{1, *(\mathbb{C}}$, Euyjoon Lee ${ }^{2} \mathbb{( \mathbb { D }}$ and Evgueniy Entchev ${ }^{3}$ \\ 1 Department of Architectural Engineering, Pusan National University, 2 Busandaehak-ro 63, \\ Geomjeong-gu, Busan 46241, Korea; ellie20@pusan.ac.kr (K.K.); sangmu_bae@pusan.ac.kr (S.B.) \\ 2 Energy Efficiency Research Division, Korea Institute of Energy Research (KIER), 152, Gajeong-ro, \\ Yuseong-gu, Daejeon 34129, Korea; ejlee@kier.re.kr \\ 3 Natural Resources Canada (NRCan), CanmetENERGY, 1 Haanel Drive, Ottawa, ON K1A 1M1, Canada; \\ evgueniy.entchev@canada.ca \\ * Correspondence: namyujin@pusan.ac.kr; Tel.: +82-51-510-7652; Fax: +82-51-514-2230
}

Citation: Kim, K.; Bae, S.; Nam, Y.; Lee, E.; Entchev, E. Development of a Low-Depth Modular GHX through a Real-Scale Experiment. Energies 2022, 15, 698. https://doi.org/10.3390/ en15030698

Academic Editor: Luca Molinaroli

Received: 6 December 2021

Accepted: 5 January 2022

Published: 18 January 2022

Publisher's Note: MDPI stays neutral with regard to jurisdictional claims in published maps and institutional affiliations.

Copyright: (C) 2022 by the authors. Licensee MDPI, Basel, Switzerland. This article is an open access article distributed under the terms and conditions of the Creative Commons Attribution (CC BY) license (https:// creativecommons.org/licenses/by/ $4.0 /)$.

\begin{abstract}
The global energy sector is aiming to rapidly transform energy systems into those less dependent on fossil fuels to reduce their harmful effects on the climate. Although ground source heat pump (GSHP) systems are more efficient than conventional air-source heat pump (ASHP) systems, the high initial investment cost, particularly for a vertical closed-loop type ground heat exchanger (GHX), makes it difficult to incorporate them into small buildings. This paper proposes a low-depth modular GHX for reducing cost and improving the workability of GSHPs. A modular GHX is a cubical structure comprising tubes and buried using an excavator at a depth $4 \mathrm{~m}$ below the ground surface. This GHX is manufactured at a factory, carried by a small truck, and then installed by a small lift or a backhoe such that it can be installed in small buildings or narrow spaces at low depths underground. In this research, the performance and feasibility analyses of modular and vertical GHXs were conducted via a real-scale experiment. The results demonstrate that the modular GHX influences the workability of GSHPs by $91 \%$ during the heating period and $70 \%$ during the cooling period. In contrast to the conventional HVAC, the modular and vertical GHXs could recover the initial investment costs in 4 years and 10 years, respectively.
\end{abstract}

Keywords: ground source heat pump; low-depth modular ground heat exchanger; heat exchange rate

\section{Introduction}

Global energy demand is gradually increasing owing to technological advances, but, owing to the indiscriminate use of fossil fuels in the past, the Earth is already facing problems such as abnormal weather and global warming. Carbon dioxide emissions from energy usage are the primary drivers of global climate change, and energy consumed by buildings accounts for $35 \%$ of the total and $38 \%$ of carbon emissions in the world (Figure 1) [1]. Despite this, reduction in the energy consumption of buildings has yet to be addressed. According to the 5th Basic Plan for Renewable Energy published by the Government of the Republic of Korea, the final energy consumption ratio between standard power and heat is $43 \%$ and $57 \%$, respectively; however, for renewable energy, an imbalance between electricity supply (73\%) and heat supply (27\%) occurs [2]. Therefore, geothermal heat pump systems are believed to be capable of supplying renewable heat energy.

Geothermal heat pump systems are gaining attention as they exhibit considerable potential as high-efficiency systems that can utilize the relative constancy of temperature of the earth throughout the year. Of these systems, $80 \%$ are vertical closed-loop type GHXs which have high costs associated with boring and drilling due to the high initial investment costs, limiting research conducted on geothermal systems. Figure 2 shows an analysis of the initial investment costs for vertical-closed loop ground heat exchangers (GHXs). Boring and drilling costs account for $35 \%$ of the total initial investment costs. (To estimate the 
initial investment cost, quotations were obtained from several geothermal construction companies in South Korea).

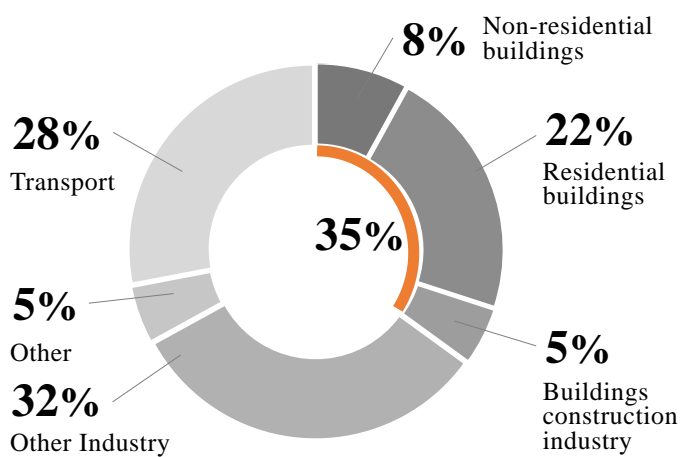

ENERGY

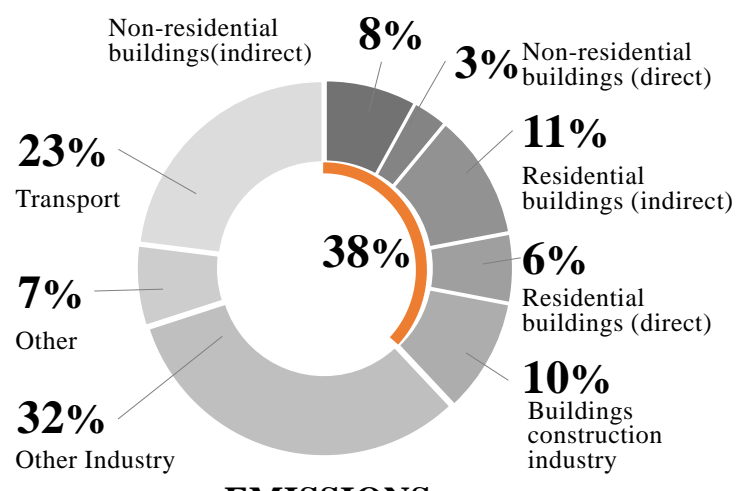

EMISSIONS

Figure 1. Global share of final energy and emissions owing to buildings and construction, 2019.

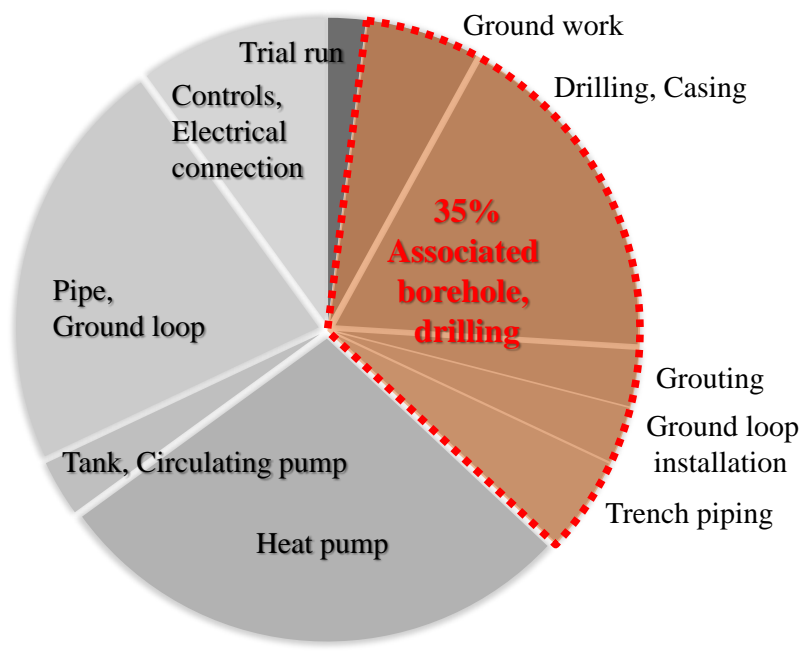

Figure 2. Share of the initial investment cost for a vertical closed-loop GHX in South Korea.

In addition, several studies have been conducted to overcome the disadvantages of conventional geothermal heat pump systems. Chen et al. proposed a numerical analysis of factors affecting the performance of vertical closed-loop GHXs [3]. The increase in the EWT velocity in the GHX enhances heat convection in the U-tube. Further, Kim et al. conducted tests to analyze the performance factors of vertical closed-loop GHXs in the long and short term [4]. Eswiasi and Mukhopadhyaya proposed an innovative design of the U-tube pipe to increase the thermal efficiency of vertical closed-loop GHXs [5]. Selamat et al. analyzed and presented the differences between the optimal pipe spacing and the material by conducting a thermal performance numerical analysis [6]. Ali et al. conducted an extraction performance analysis according to the shape of horizontal GHXs [7]. Piselli et al. conducted studies on historical buildings, focusing on energy repair and building energy performance, using horizontal GHXs [8]. Studies have been conducted on improving the efficiency and performance of GHXs; however, a new GHX that could be installed even at low depths was required, with economical drilling and boring costs. Therefore, this paper presents low-depth modular GHXs. Kim et al. conducted extensive research on low-depth modular GHXs [9]. The extraction performance of the modular geothermal heat exchanger was analyzed via a numerical analysis, and the feasibility of the modular geothermal exchanger was compared with that of the existing air conditioning system and the vertical GHXs. In addition, studies have been conducted to better predict the performance of modular GHXs via numerical analyses [10]. However, limited empirical studies have been 
conducted on low-depth modular GHXs. Further, the performances of vertical closed-loop GHXs and low-depth modular GHXs have not been sufficiently compared under the same conditions. When developing new systems, empirical data are crucial for securing the reliability of the system; further, when developing low-depth modular GHXs, data should be obtained during the demonstration testing phase. In addition, comparative analyses with closed-loop GHXs under the same ground conditions are essential for performance verification of low-depth modular GHXs under development, as GHXs are considerably affected by load. Therefore, in this paper, we propose a modular GHX that can be installed at low depths and compare its performance with that of a vertical closed-loop GHX of the same length to determine the feasibility of the proposed low-depth modular GHX.

\section{Low-Depth Modular GHX}

The modular GHX, which can be installed at low depths $(2-10 \mathrm{~m})$, reduces the initial investment cost associated with the drilling and boring of vertical closed-loop GHXs. Compared with horizontal closed-loop GHXs, which are heavily affected by surface flux, vertical closed-loop GHXs can be installed at a slightly deeper depth; further, concrete can be poured on the vertical closed-loop GHXs to prevent pipe loss to cope with pipe breakage during the installation process. In addition, preface-style, pre-factory-built hooks that could facilitate the transfer of GHXs to trucks were installed everywhere for ease of construction. In addition, the number of modular units can be varied and installed according to the building load. The proposed modular GHX can be applied to small buildings or urban areas with less installation space. Figure 3 shows an overview of the low-depth modular GHX.

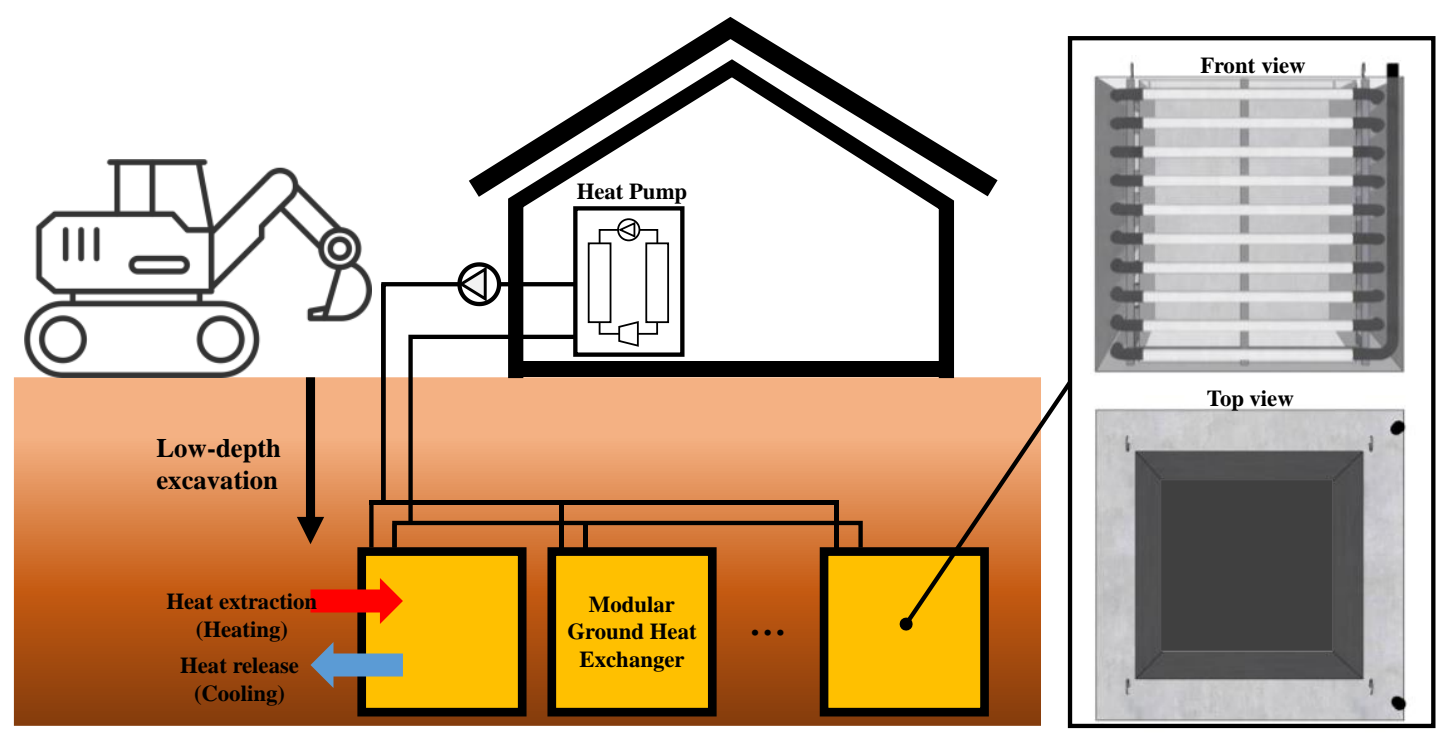

Figure 3. Conceptual design of the low-depth modular GHX.

\section{Research Method \\ Set-Up of Real-Scale Experiment}

Herein, a real-scale experiment site was set up to understand the heat exchange rate (HER) of the modular GHX during heating and cooling periods to compare the performance of the modular GHX and vertical GHX under the same conditions. The experiment site was located in Yangsan, South Korea (latitude $35.4^{\circ} \mathrm{N}$, longitude $129.1^{\circ} \mathrm{E}$ ). The average temperature and precipitation in Yangsan were $15^{\circ} \mathrm{C}$ and $1892.5 \mathrm{~mm}$, respectively. Figure 4 shows a schematic of the demonstration site and indicates the location of the temperature sensor installation. Three modules of the modular GHX were connected in parallel, $4 \mathrm{~m}$ below ground level, and separated by a distance of $1 \mathrm{~m}$. The total pipe length of one modular GHX unit is $67.3 \mathrm{~m}$. A vertical GHX with a length equal to that of one modular GHX was manufactured and installed. In addition, a temperature sensor was installed $1 \mathrm{~m}$ 
from the GHX at a depth of $3 \mathrm{~m}$ to measure the temperature before and after the operation of the modular GHX to analyze the temperature change. Reference temperature sensors were installed $6 \mathrm{~m}$ from the modular GHX to observe the changes in its temperature as it continued to operate. Each feature is listed in Table 1. Figure 5 shows the demonstration site. As with Figure 5a, the modular GHX was pre-produced and transported to the demonstration site and installed by excavating the ground using a backhoe, as shown in Figure $5 b$. Figure $5 c$ is a photo of the devices used and the demonstration sites.

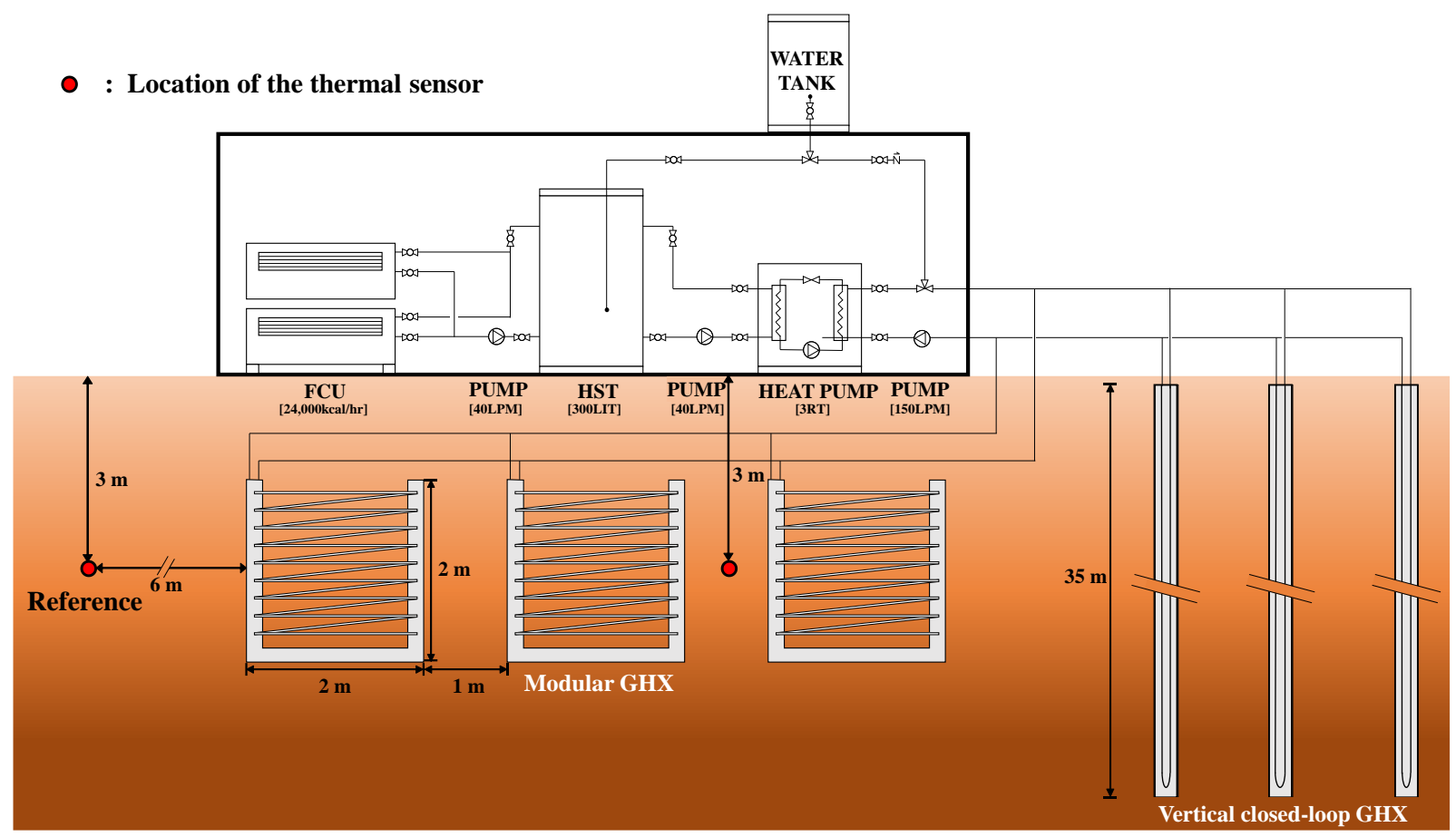

Figure 4. Real-scale experimental site.

Table 1. Specifications of the modular and vertical GHXs.

\begin{tabular}{ccc}
\hline & Modular GHX & Vertical GHX \\
\hline Pipe diameter & & $40 \mathrm{~A}$ \\
Pipe length & $67.27 \mathrm{~m}$ & $70 \mathrm{~m}$ \\
Heat transfer area/Unit & $8.45 \mathrm{~m}^{2}\left(25.36 \mathrm{~m}^{2}\right)$ & $8.80 \mathrm{~m}^{2}\left(26.40 \mathrm{~m}^{2}\right)$ \\
Pipe material & HDPE (High-density polyethylene) \\
\hline
\end{tabular}

Cases 1 and 2 are used when the modular GHX is operated alone to check the underground temperature. In addition, Cases 3 and 4 were performed to compare the heat collection performance of the modular and vertical GHXs under the same conditions (underground, ambient air temperature, and load conditions). We also proceeded with Cases 5 and 6 to determine the COP (Coefficient of performance) for each modular and vertical closedloop GHX (Table 2). Table 3 summarizes the temperature limit during heating and cooling, along with the heat source and the heat storage tank. The heat source temperature-limiting condition is to exclude the cases where the use of the air-source heat pump is an advantage. In addition, the HST limit temperature is for proper heating and cooling operation. 

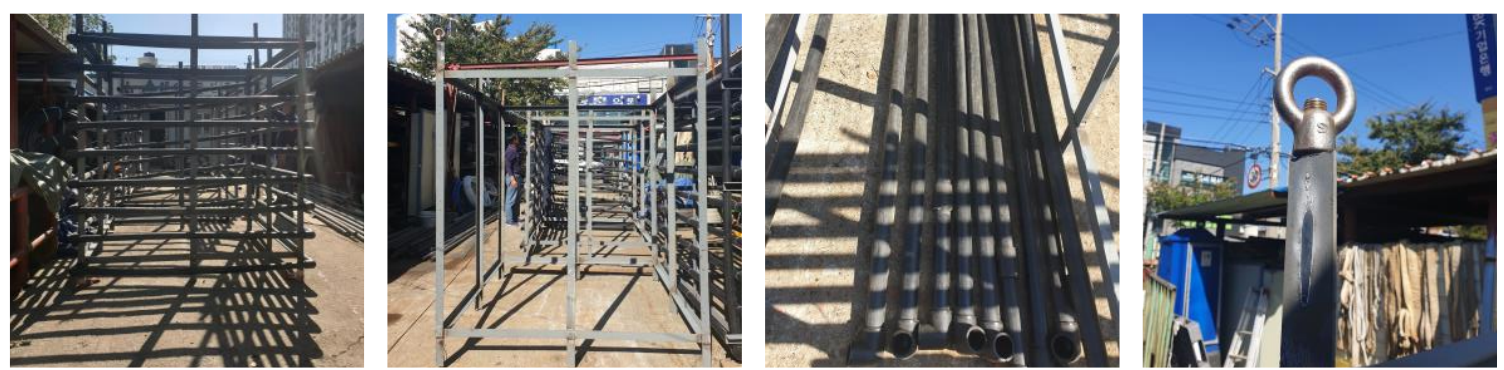

(a) Prodution process of Modular GHX
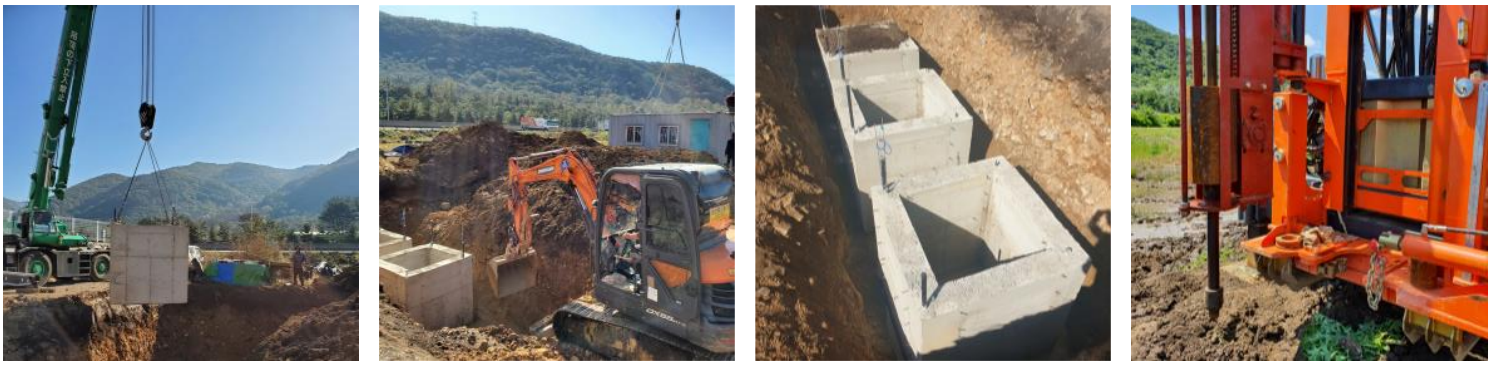

(b) Installation process
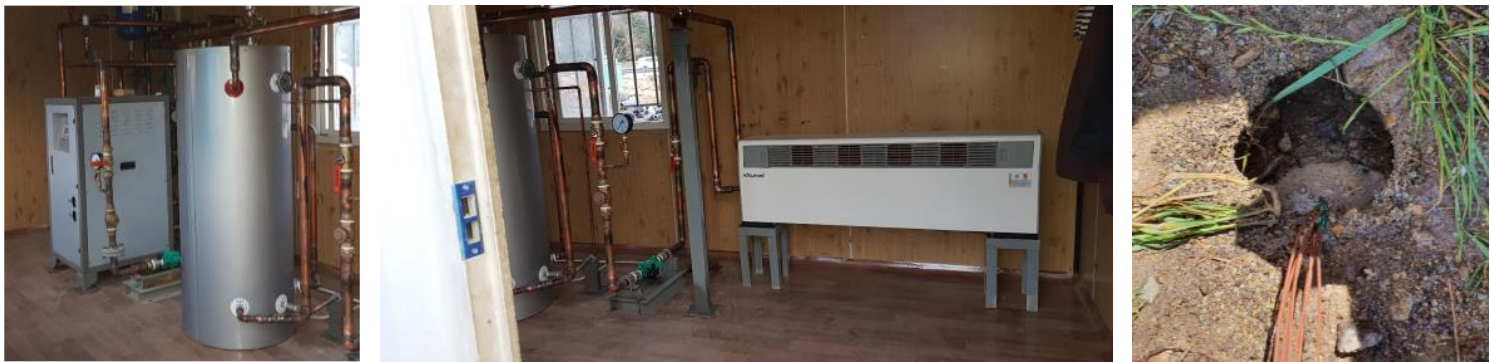

(c) Construction of demonstration site

Figure 5. Demonstration site.

Table 2. Experimental conditions.

\begin{tabular}{|c|c|c|c|c|c|c|}
\hline Case & GHX & $\begin{array}{l}\text { Operating } \\
\text { Period }\end{array}$ & Mode & Flow Rate & $\begin{array}{c}\text { FCU } \\
\text { Capabilities }\end{array}$ & Purpose \\
\hline 1 & Modular & $\begin{array}{l}\text { 3rd February-28th } \\
\text { February }\end{array}$ & Heating & 85 LPM & \multirow{6}{*}{$\begin{array}{l}\text { Heating: } \\
\text { 24,600 kcal/h } \\
\text { Cooling: } \\
\text { 17,600 kcal/h }\end{array}$} & \multirow{2}{*}{$\begin{array}{l}\text { For analyzing the } \\
\text { underground temperature }\end{array}$} \\
\hline 2 & Modular & 23rd June-18th July & Cooling & 85 LPM & & \\
\hline 3 & $\begin{array}{l}\text { Modular }+ \\
\text { Vertical }\end{array}$ & $\begin{array}{c}\text { 3rd February-28th } \\
\text { February }\end{array}$ & Heating & $\begin{array}{l}\text { Modular: } 70 \text { LPM } \\
\text { Vertical: } 70 \text { LPM }\end{array}$ & & \multirow{2}{*}{$\begin{array}{l}\text { For comparison of the heat } \\
\text { exchange rate between the } \\
\text { modular and vertical GHX }\end{array}$} \\
\hline 4 & $\begin{array}{l}\text { Modular + } \\
\text { Vertical }\end{array}$ & 15th June-27th June & Cooling & $\begin{array}{l}\text { Modular: } 70 \text { LPM } \\
\text { Vertical: } 75 \text { LPM }\end{array}$ & & \\
\hline 5 & Modular & 3th June-8th June & Cooling & 54 LPM & & \multirow{2}{*}{$\begin{array}{c}\text { For COP comparison of } \\
\text { each GHX }\end{array}$} \\
\hline 6 & Vertical & 31st May-3rd June & Cooling & 50 LPM & & \\
\hline
\end{tabular}

Table 3. Mode-setting conditions.

\begin{tabular}{ccc}
\hline Mode & $\begin{array}{c}\text { Limited Temperature of the } \\
\text { Heat Source }\end{array}$ & Limited Temperature of HST \\
\hline Heating & $4{ }^{\circ} \mathrm{C}$ & $50^{\circ} \mathrm{C}$ \\
Cooling & $30^{\circ} \mathrm{C}$ & $10^{\circ} \mathrm{C}$ \\
\hline
\end{tabular}

The amount of underground heat collected at this time was calculated using the temperature difference between the entrance and exit of the underground heat exchanger, as follows:

$$
\mathrm{Q}=\mathrm{c} \times \mathrm{m} \times(\mathrm{EWT}-\mathrm{LWT})[W]
$$


(Q: calorific value $(\mathrm{W})$, c: specific heat $\left(\mathrm{kJ} / \mathrm{kg}{ }^{\circ} \mathrm{C}\right), \mathrm{m}$ : mass $(\mathrm{kg})$, EWT $(\mathrm{C})$, and $\mathrm{LWT}\left({ }^{\circ} \mathrm{C}\right)$ ) The coefficient of performance was calculated as follows:

$$
\mathrm{COP}=\frac{E_{t h}}{E_{e l}}
$$

$\left(E_{t h}\right.$ : output thermal energy $(\mathrm{kWh})$ and $E_{e l}$ : input electrical energy consumption $\left.(\mathrm{kWh})\right)$

\section{Experiment Result}

\subsection{EWT Temperature Change Analysis}

In this experiment, the performance of the modular and vertical GHXs was compared under the same conditions (external temperature, load condition, flow rate, building load, etc.). Figure 6 shows the temperature difference between the modular and vertical GHXs in terms of EWT (entering water temperature) and LWT (leaving water temperature) during the heating period (Case 3). Before the operation, the temperature was approximately $15.6^{\circ} \mathrm{C}$; however, after the operation commenced, the EWT of the modular GHX decreased to $9.9^{\circ} \mathrm{C}$, and the EWT of the vertical GHX to $10.4^{\circ} \mathrm{C}$. This is believed to be because the EWT of the vertical GHX returns owing to the extraction of the underlying heat at depths of $30 \mathrm{~m}$ or more with a higher underground temperature. In response, the EWT of the vertical GHX tended to be $4.8 \%$ higher. Moreover, the temperature differences between the modular and vertical GHXs in terms of EWT and LWT were $15.1 \%$ at $1.33^{\circ} \mathrm{C}$ and $1.57^{\circ} \mathrm{C}$, respectively. The external temperature at which the experiment was conducted was $5.9^{\circ} \mathrm{C}$, and the temperature of the $3 \mathrm{~m}$ load was $16.8^{\circ} \mathrm{C}$; further, the EWT is considered to be more advantageous in terms of efficiency compared with the conventional air-heat-based heat pumps, as the EWT is $9.9^{\circ} \mathrm{C}$ for the modular GHX and $10.4{ }^{\circ} \mathrm{C}$ for the vertical GHX.

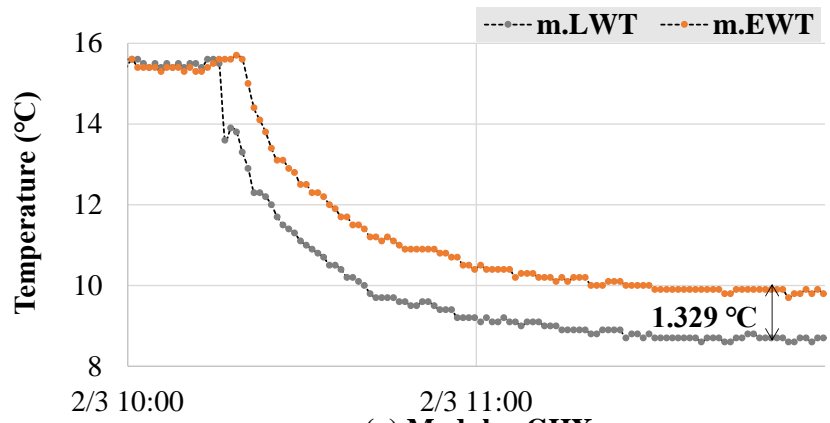

(a) Modular GHX

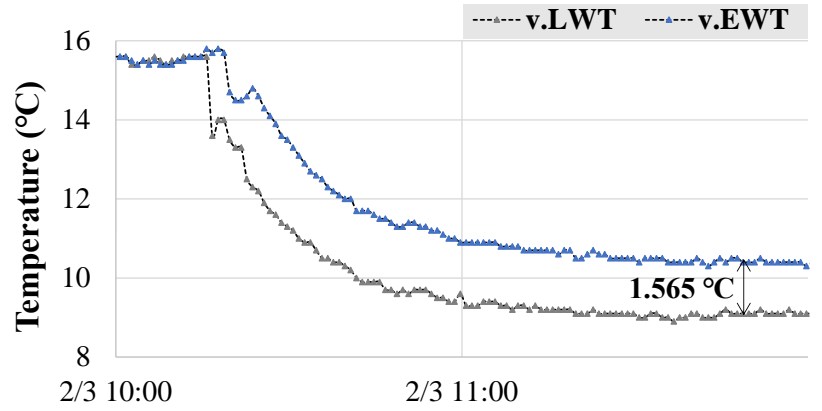

(b) Vertical GHX

Figure 6. EWT and LWT temperature difference during heating.

Figure 7 shows the difference in EWT and LWT temperatures during cooling (Case 4). The external temperature was approximately $24.1-23^{\circ} \mathrm{C}$ before the start of the operation; however, as the operation commenced, the temperature of the modular GHX dropped to $17.3^{\circ} \mathrm{C}$ and that of the vertical GHX, which was $30 \mathrm{~m}$ deeper, dropped to $16.5^{\circ} \mathrm{C}$. Cooling began and the EWTs of the modular and vertical GHXs increased to $22.0^{\circ} \mathrm{C}$ and $21.5^{\circ} \mathrm{C}$, respectively. The EWT of the vertical GHX $\left(1.83^{\circ} \mathrm{C}\right)$ differed by $26.6 \%$ from the LWT $\left(2.49^{\circ} \mathrm{C}\right)$. The temperature of the $3 \mathrm{~m}$ load was $17.4^{\circ} \mathrm{C}$. 

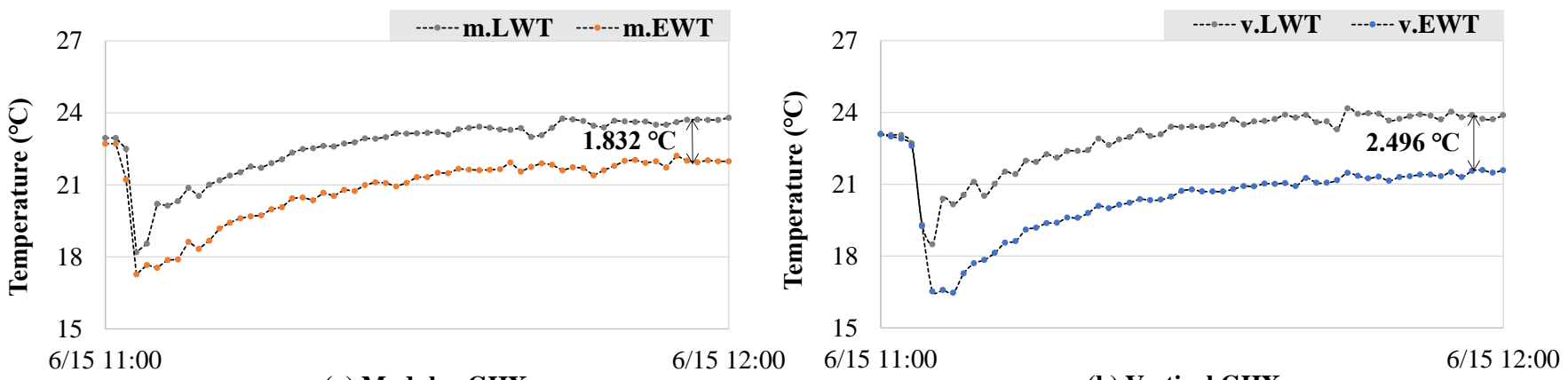

(a) Modular GHX

(b) Vertical GHX

Figure 7. EWT and LWT temperature difference during cooling.

\subsection{HER Analysis}

Figures 8 and 9 show the HER during heating and cooling when operating long-term operation without considering recovery operation. The vertical GHX's heating HER during operation was averaged at $5.86 \mathrm{kWh}$ and the cooling HER at $11.17 \mathrm{kWh}$. The modular GHX's heating HER during operation was averaged at $4.65 \mathrm{kWh}$ and the cooling HER at $6.44 \mathrm{kWh}$. When the recovery operation was not considered during heating, the HER for the vertical GHX was $5.24 \mathrm{kWh}$ and for the modular GHX it was $3.80 \mathrm{kWh}$; further, during extraction, it was $10.60 \mathrm{kWh}$ for the vertical GHX and $5.52 \mathrm{kWh}$ for the modular GHX. Instead of long-term continuous operation, if the operation corresponded to the building's preemptive schedule, higher efficiency was observed.

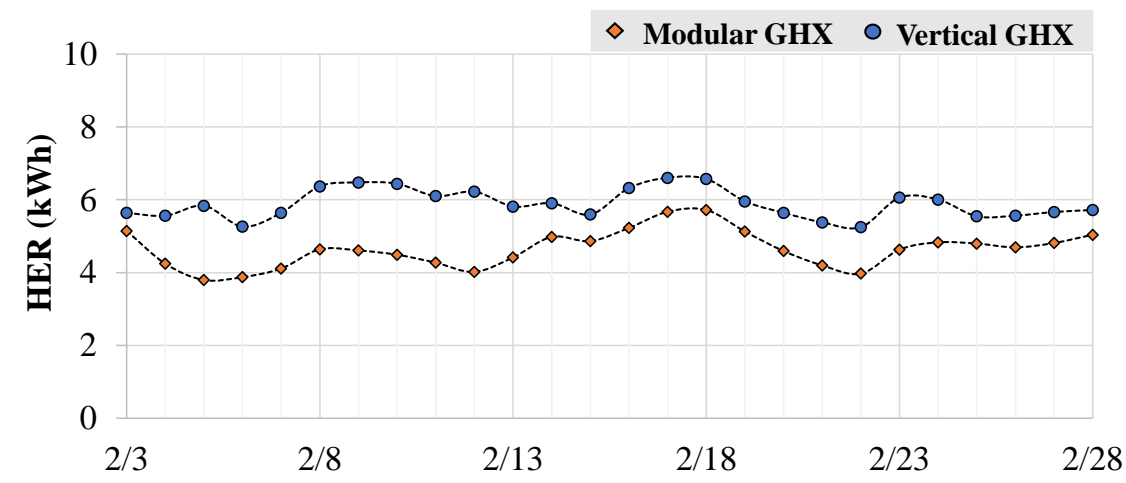

Figure 8. HER comparison during heating.

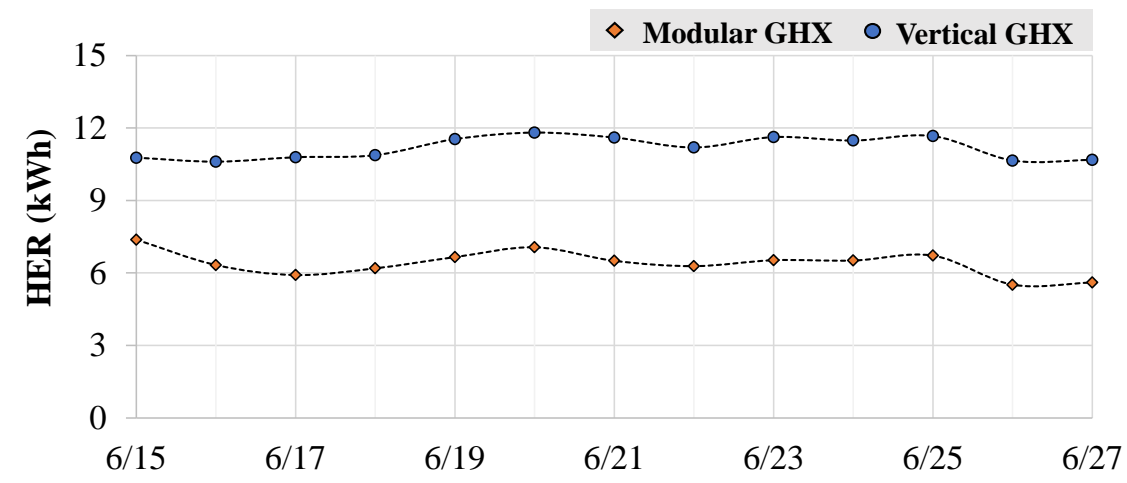

Figure 9. HER comparison during cooling.

\subsection{Underground Temperature Analysis}

To determine the change in the designated temperature during the operation period of the modular GHX, a temperature sensor was installed $3 \mathrm{~m}$ between the modular units. 
Then, the temperature at the reference point was measured to determine the change in the ground temperature during extraction and injection while the heat pump was activated.

Figure 10 shows a change in the ground temperature during heating (Case 1); the initial ground temperature of $16{ }^{\circ} \mathrm{C}$ dropped to $7.6^{\circ} \mathrm{C}$. This showed that the operation began to change to extraction of the underlying temperature, and the ground temperature remained at a similar level until 14 February. Figure 11 shows that at a ground temperature of $14{ }^{\circ} \mathrm{C}$, the cooling operation commenced at $25.6^{\circ} \mathrm{C}$, as heat release continued. Operation (Case 2) began and continued to increase for 15 days but has since remained at a similar level. This is believed to be because the limit temperature of the heat source during heating was set to $4{ }^{\circ} \mathrm{C}$, and the limit temperature of the heat source during cooling to $30^{\circ} \mathrm{C}$. If a complex heat-source system was established to restore the temperature, higher efficiency could be observed.

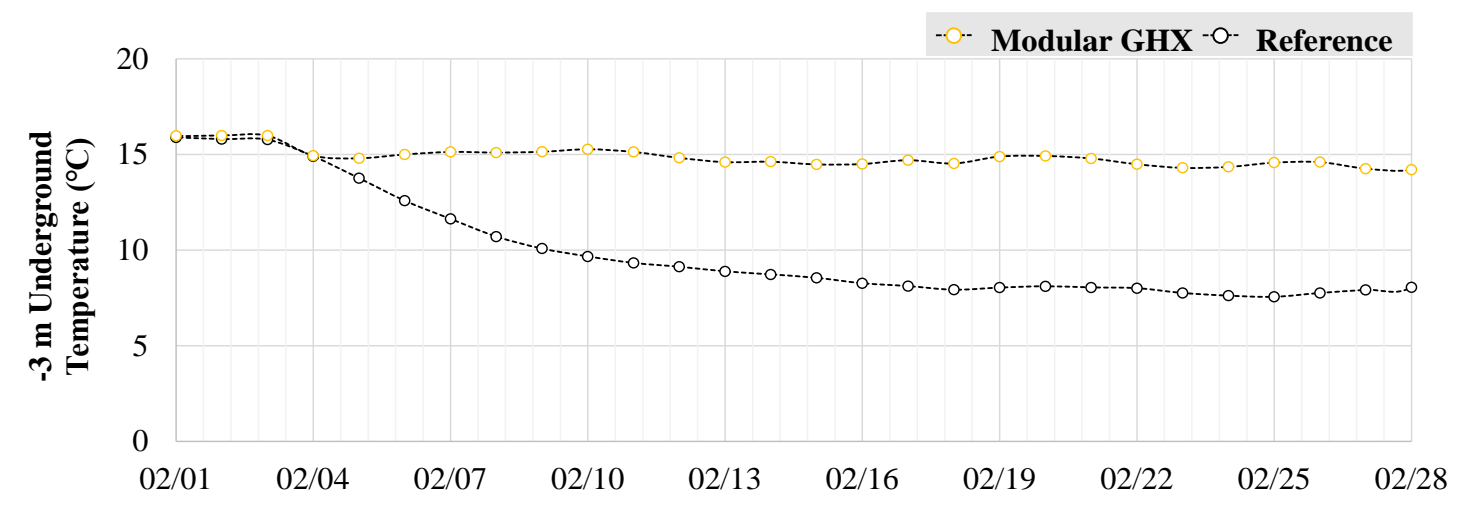

Figure 10. Temperature change in ground $(-3 \mathrm{~m})$ during heating.

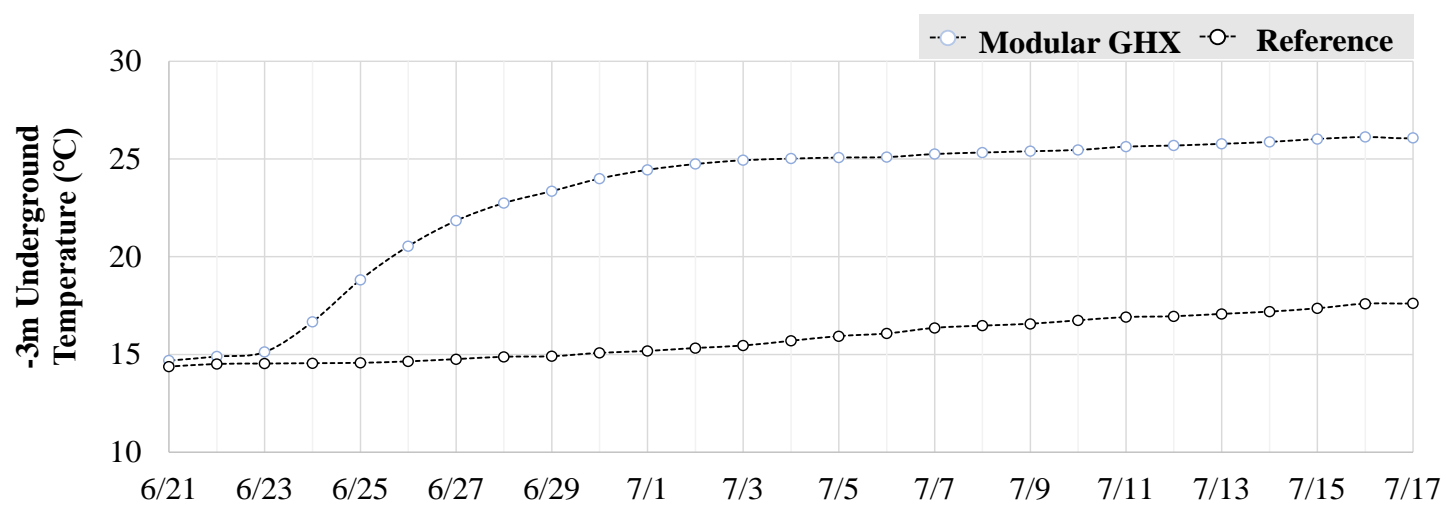

Figure 11. Temperature change in the load $(-3 \mathrm{~m})$ during cooling.

\subsection{Performance Comparison and COP Analysis}

Figure 12 shows a graph of the HER vs. the temperature differences between EWT and LWT during the initial 24-h operation for comparing the performances of the vertical and modular GHXs (Case 5, 6). The HER of the modular GHX was $5.14 \mathrm{kWh}$ and that of the vertical GHX was $5.63 \mathrm{kWh}$, demonstrating that the modular GHX is $91 \%$ more compatible than the vertical GHX. Further, the EWT and LWT temperature differences were $1.01{ }^{\circ} \mathrm{C}$ and $1.11^{\circ} \mathrm{C}$, respectively. The modular GHX with extraction at a depth of $4 \mathrm{~m}$ showed a temperature difference as low as $0.1^{\circ} \mathrm{C}$. In addition, the HER of the modular GHX was $7.38 \mathrm{kWh}$ and that of the vertical GHX was $10.77 \mathrm{kWh}$, i.e., the HER of the modular GHX was $70 \%$ of that of the vertical GHX during cooling. Further, the EWT and LWT temperature differences were $1.52{ }^{\circ} \mathrm{C}$ and $2.17^{\circ} \mathrm{C}$, respectively. 


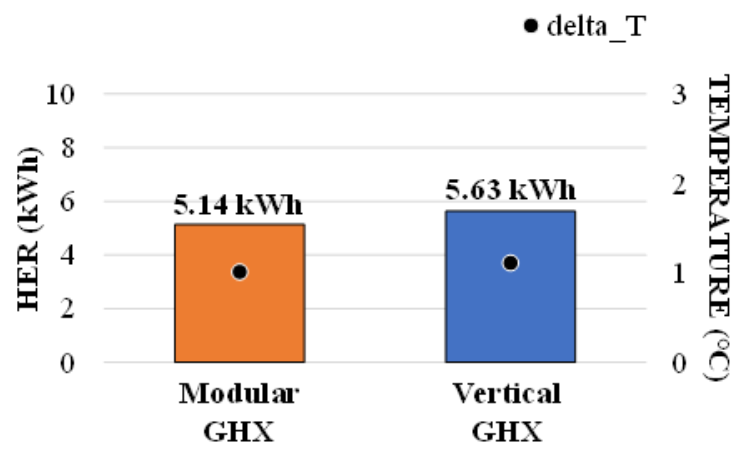

(a) Heating Period

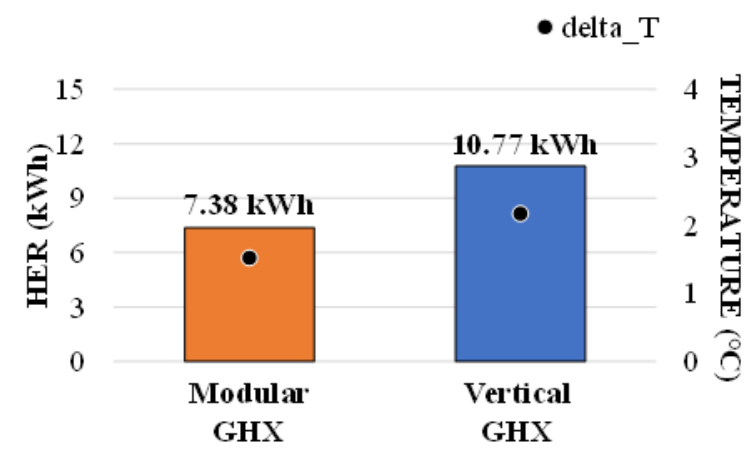

(b) Cooling Period

Figure 12. Performance comparison between heating and cooling.

The average COPc over the same period was 4.02 for the modular GHX and 4.24 for the vertical GHX (Figure 13). A high EWT was supplied to the modular GHX installed at low depths; therefore, the COPc was relatively low, and the difference was $4.7 \%$.

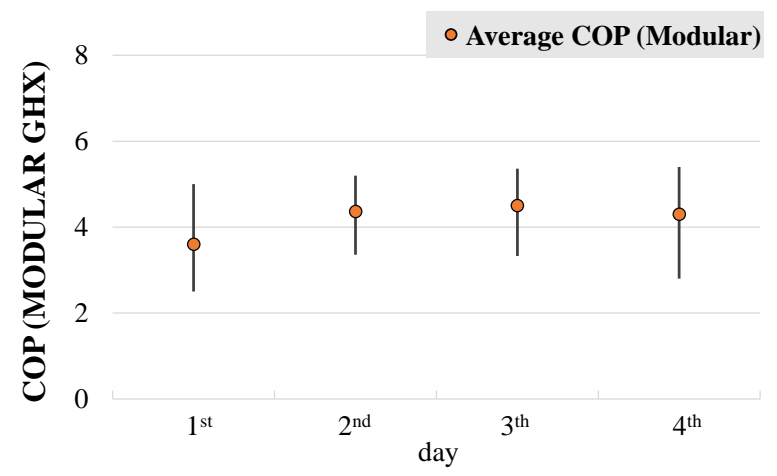

(a) Modular GHX

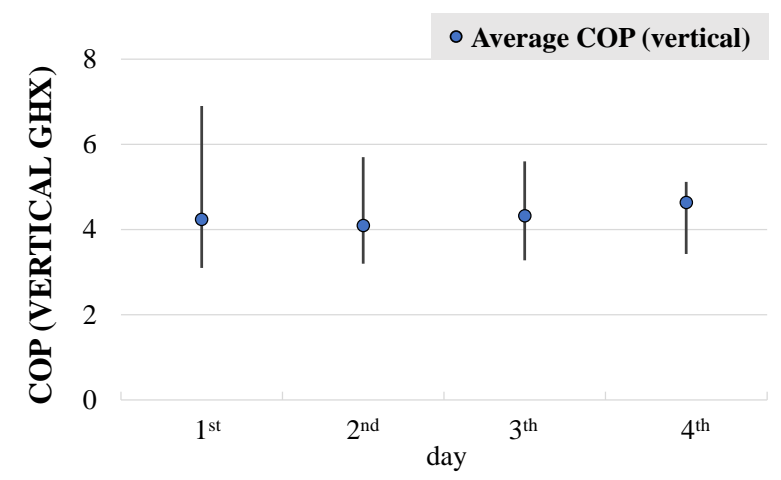

(b) Vertical GHX

Figure 13. Comparison of COPc.

\section{Feasibility Analysis}

\subsection{Introduction Feasibility Overview}

In this study, to examine the feasibility of the introduction of modular GHXs instead of vertical GHXs, the initial investment cost recovery period was compared with the existing air conditioning system, and this was further utilized as an indicator of economic analysis. All costs, including the initial investment cost, operating cost, and replacement and repair costs, were converted to the current value by applying the net present value (NPV) method. The applied NPV method is the same as the expression (3) to the expression (5) [11]. The actual discount rate was calculated as $1.14 \%$ by assuming a nominal discount rate of $3.50 \%$, the average value of the three-year Treasury yield during the Bank of Korea's 11-year (2006-2015) period, and applying the average inflation rate of $2.33 \%$ over the last 11 years.

$$
\begin{gathered}
P_{F}=\frac{F}{(1+i)^{n}} \\
P_{A}=\frac{A\left[(1+i)^{n}-1\right]}{i(1+i)^{n}} \\
i=\frac{(1+i)}{(1+k)}-1
\end{gathered}
$$

where $P_{F}$ represents the current value of non-recurring cost after $n$ years, $P_{A}$ represents the current value of repeat cost after $n$ years, and $F_{N}$ represents the non-recurring cost a year 
later. Moreover, $A$ is the recurring cost, $I$ is the actual factor, $j$ is the nominal rate, and $k$ is the inflation rate.

The PNNL standard housing model was selected as the target building for introduction feasibility analysis (Figure 14). The dynamic thermal energy analysis simulation program TRNSYS analyzed the cooling and cooling load of the target building and calculated the system capacity (Table 4). The simulation input conditions were based on ASHRAE 90.1-2004 [12,13], and the U-value met the building energy-saving design standards [14]. Air-conditioned operation hours considered the conditions of single-family homeowners (Table 5) [15]. The cooling and heating peaks of the building were $9.26 \mathrm{~kW}$ and $4.42 \mathrm{~kW}$, respectively.

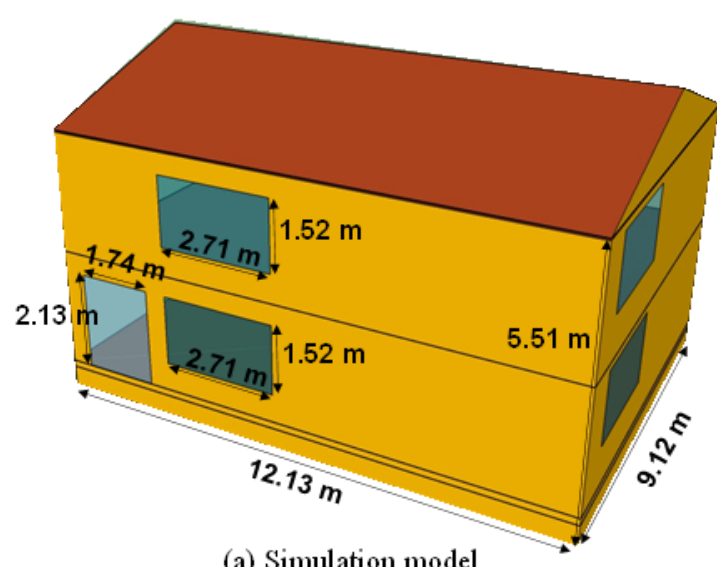

(a) Simulation model

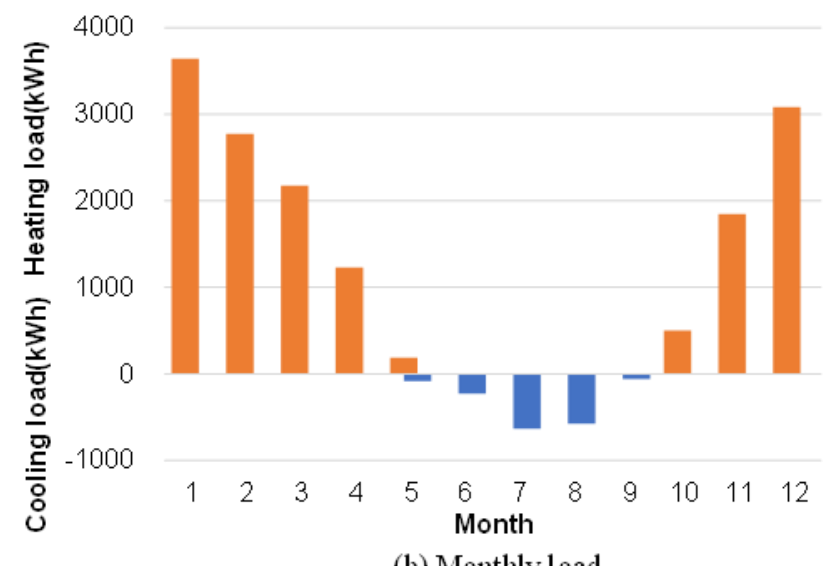

(b) Monthly load

Figure 14. Simulation model and monthly load.

Table 4. Characteristics of the building.

\begin{tabular}{cc}
\hline Parameter & Assumption \\
\hline Conditioned floor area & $220.7 \mathrm{~m}^{2}$ \\
Height & two-story, $2.59 \mathrm{~m}$ \\
Perimeter length & $42.5 \mathrm{~m}$ \\
Window area & Fifteen percent equally distributed to the four cardinal directions \\
Door area & $3.71 \mathrm{~m}^{2}$ \\
\hline
\end{tabular}

Table 5. Simulation input parameters.

\begin{tabular}{cc}
\hline Parameter & Input Value \\
\hline People & $2.7 / 100 \mathrm{~m}^{2}$ \\
People sensible heat gain & $70 \mathrm{~W} /$ person \\
People latent heat gain & $45 \mathrm{~W} /$ person \\
Lighting power density (LPD) & $10.76 \mathrm{~W} / \mathrm{m}^{2}$ \\
Electric power density (EPD) & $2.69 \mathrm{~W} / \mathrm{m}^{2}$ \\
Infiltration flow & $0.7 / \mathrm{h}$ \\
Heating setting temperature & $20^{\circ} \mathrm{C}$ \\
Cooling setting temperature & $26{ }^{\circ} \mathrm{C}$ \\
Insulation condition & Energy-saving design standard \\
\hline
\end{tabular}

\subsection{Estimating Initial Investment Costs}

The installation cost was based on the actual geothermal construction company's quote and the reference price per renewable energy source [16]. Moreover, the initial investment cost of the geothermal exchanger was the same as is listed in Table 6. The installation cost was calculated by considering the air-conditioning area of the 3RT capacity according to the load of the target building [17]. Initial investments in modular GHX, 
vertical GHX, and existing air conditioning systems were 12,650 USD, 24,020 USD, and 8,420 USD, respectively. The modular GHX was able to reduce initial investment costs by an average of $47 \%$ compared with the vertical GHX.

Table 6. Cost comparison between vertical GHX and modular GHX.

\begin{tabular}{ccc}
\hline & Modular GHX & Vertical GHX \\
\hline Excavation & 620 USD & 4770 USD \\
Pipe casing & - & 350 USD \\
Grouting & 440 USD & 620 USD \\
Making & 1770 USD & 620 USD \\
Labor & 270 USD & 530 USD \\
Total & 3100 USD & 6890 USD \\
\hline
\end{tabular}

\subsection{Estimating Annual Operation Costs}

Since 2009, the South Korean government has provided general electricity bills instead of progressives to geothermal cold and heating electricity bills to revitalize the housing supply for renewable energy. Therefore, the geothermal cooling and heating charges were calculated by applying a general electricity charge and the cooling charge of the existing air conditioning system by applying progressive agents. For calculating operating costs, COP used the values of 4.04 and 4.24 calculated through estimation tests, and the air-heatsource system was assumed to be 2.5. The modular GHX's performance was evaluated by assuming heating of $5.14 \mathrm{kWh}$ and cooling of $7.38 \mathrm{kWh}$. The performance of the vertical GHX was evaluated by assuming heating of $5.63 \mathrm{kWh}$ and cooling of $10.77 \mathrm{kWh}$. In addition, $84 \%$ heating efficiency was obtained by selecting a company $\mathrm{K}$ household oil boiler to calculate the heating fee of the existing air conditioning system, and the diesel price was referenced to the domestic oil price trend. Table 7 lists the COP and annual operation costs for each system based on this. The annual cost of the existing air conditioning system was the highest at 1830 USD, whereas the geothermal heat pump system with the modular GHX at 542 USD and vertical GHX at 510 USD, which was only $30 \%$ of the conventional HVAC system.

Table 7. Cost comparison between vertical GHX and modular GHX.

\begin{tabular}{cccc}
\hline & \multicolumn{3}{c}{ Annual Operation Cost } \\
& Conventional System & Vertical GHX & Modular GHX \\
\hline Heat pump COP & 2.50 & 4.24 & 4.04 \\
Annual operation cost & 1830 USD & 510 USD & 542 USD \\
\hline
\end{tabular}

\subsection{Introduced Feasibility Analysis Results}

To review the feasibility of modular GHX and vertical GHX production, installation costs were compared and reviewed based on 3RT capacity. The initial investment costs for the modular GHX and vertical GHX per unit were 3100 USD and 6890 USD, respectively, and modular geothermal exchangers saved approximately $55 \%$ more than vertically closed geothermal exchangers. The annual operation costs of the vertical GHX, modular GHX, and existing air conditioning systems were 510 USD, 542 USD, and 1,850 USD, respectively. The initial investment cost recovery period was analyzed to be 4 years for the modular GHX and 10 years for the vertical GHX. Therefore, it was found that the LCC gradient change was similar for both the vertically closed and modular GHXs, but the factor having a significant economic impact was the initial investment cost, as shown in Figure 15. 


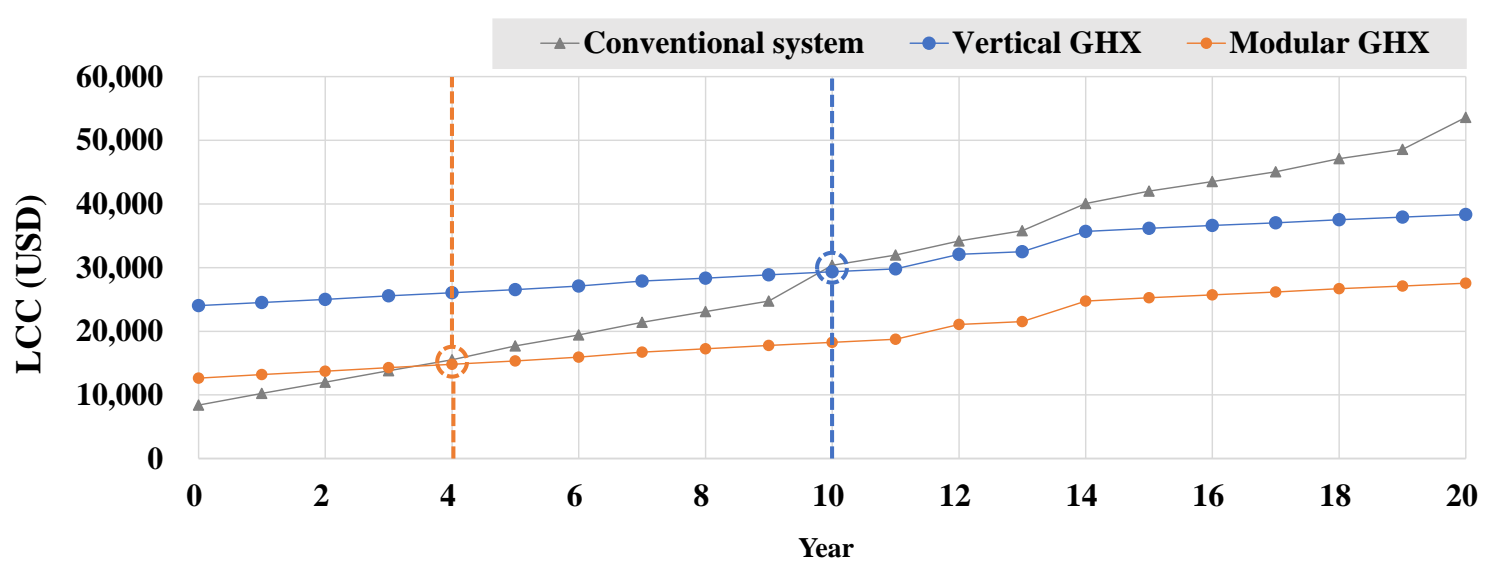

Figure 15. Payback period.

\section{Conclusions}

In this study, an empirical site was established to compare the performance of a modular GHX and vertical GHX under the same conditions. Moreover, the possibility of the introduction of modular GHXs through feasibility analysis was analyzed.

(1) During heating, the HER test results of the modular GHX and the vertical GHX was $5.14 \mathrm{kWh}$ and $5.63 \mathrm{kWh}$, respectively, showing that the modular GHX can perform at $91 \%$ of the level of the vertical GHX. During cooling, the HER test results of the modular GHX and the vertical GHX were $7.38 \mathrm{kWh}$ and $10.77 \mathrm{kWh}$, respectively, showing that the modular GHX can perform at $70 \%$ of the level of the vertical GHX.

(2) During continuous operation experiments, the $3 \mathrm{~m}$ temperature of the load on the modular side was lowered by $8.4^{\circ} \mathrm{C}$ when heating; however, the temperature increased by $11.6{ }^{\circ} \mathrm{C}$ during cooling operation. With the introduction of optimal control or a combined-heat-source system, higher efficiency can be expected if the ground temperature recovery is considered for operation.

(3) The initial investment cost per unit was a saving of $55 \%$ with the modular GHX at 3100 USD and the vertical GHX at 6890 USD.

(4) The COPc for the modular GHX and vertical GHX was 4.04 and 4.24, respectively. The annual operation cost was 6\% higher for the modular GHX at 542 USD, with that of the vertical GHX at 510 USD.

(5) The feasibility of introducing the modular GHX was analyzed, and it was found that the initial investment cost recovery period for the vertical GHX and the modular GHX is 10 and 4 years, respectively. Therefore, introducing the modular GHX was valid, and the factor that had the largest impact on economic feasibility was the initial investment cost.

The module GHX can perform at $80 \%$ of the vertical closed-loop GHX and reduce initial investment costs by 55\%. The initial investment cost of the modular GHX varied depending on the depth of installation, the number of installation units, and the type of ground, but compared to vertical closed-loop GHX, where drilling and boring are essential, the economic feasibility was outstanding. Owing to the low initial investment and operating costs compared to conventional HVAC systems, the modular GHX was found to be a valid system considering the increasing life cycle of buildings, and it is expected to be applicable in urban areas and small buildings.

Author Contributions: K.K., S.B. and Y.N. carried out the real-scale experiment and wrote the entire manuscript. Y.N. reviewed the results and the entire manuscript. E.L. supported the planning of the experiment system. E.E. reviewed the results of the heat exchange rate data. All authors have read and agreed to the published version of the manuscript. 
Funding: This study was supported by the Korean Institute of Energy Technology Evaluation and Planning (KETEP) and the Ministry of Trade, Industry \& Energy (MOTIE) of the Republic of Korea, grant number 20188550000430.

Institutional Review Board Statement: Not applicable.

Informed Consent Statement: Not applicable.

Data Availability Statement: Not applicable.

Conflicts of Interest: The authors declare no conflict of interest.

$\begin{array}{ll}\text { Abbreviations } \\ \text { GSHP } & \text { Ground source heat pump } \\ \text { GHX } & \text { Ground heat exchanger } \\ \text { EWT } & \text { Entering water temperature } \\ \text { LWT } & \text { Leaving water temperature } \\ \text { HDPE } & \text { High-density polyethylene } \\ \text { HP } & \text { Heat pump } \\ \text { FCU } & \text { Fan coil unit } \\ \text { HST } & \text { Heat storage tank } \\ \text { LPM } & \text { Liter per meter } \\ \text { RT } & \text { Refrigeration ton } \\ \text { COP } & \text { Coefficient of performance } \\ \text { NPV } & \text { Net present value } \\ \text { PNNL } & \text { Pacific Northwest National Laboratory } \\ \text { LCC } & \text { Life cycle cost }\end{array}$

\section{References}

1. Global Alliance for Buildings and Construction. 2020 Global Status Report for Buildings and Construction 2020-12; Un Environment Programme: Nairobi, Kenya, 2020.

2. The Ministry of Trade, Industry and Energy. Announcement of the 5th Renewable Energy Master Plan (2020-2034); Government of Republic of Korea, 2020; Available online: https://www.korea.kr/news/pressReleaseView.do?newsId=156429610 (accessed on 2 December 2021).

3. Chen, S.; Mao, J.; Han, X.; Li, C.; Liu, L. Numerical analysis of the factors influencing a vertical U-tube ground heat exchanger. Sustainability 2016, 8, 882. [CrossRef]

4. Kim, H.; Nam, Y.; Bae, S.; Choi, J.; Kim, S. A study on the effect of performance factor on GSHP System through real-scale experiments in Korea. Energies 2020, 13, 554. [CrossRef]

5. Eswiasi, A.; Mukhopadhyaya, P. Performance of conventional and innovative single U-tube pipe configuration in vertical ground heat exchanger (VGHE). Sustainability 2021, 13, 6384. [CrossRef]

6. Selamat, S.; Miyara, A.; Kariya, K. Analysis of short time period of operation of horizontal ground heat exchangers. Resources 2015, 4, 507-523. [CrossRef]

7. Ali, M.; Kariya, K.; Miyara, A. Performance analysis of slinky horizontal ground heat exchangers for a ground source heat pump system. Resources 2017, 6, 56. [CrossRef]

8. Piselli, C.; Guastaveglia, A.; Romanelli, J.; Cotana, F.; Pisello, A. Facility energy management application of HBIM for historical low-carbon communities: Design, modelling and operation control of geothermal energy retrofit in a real Italian case study. Energies 2020, 13, 6338. [CrossRef]

9. Kim, J.; Bae, S.; Nam, Y. Performance and feasibility analysis on the unit-type ground heat exchanger under a building. Korean J. Air-Cond. Refrig. Eng. 2018, 30, 228-236.

10. Kim, J.; Nam, Y. Development of the performance prediction equation for a modular ground heat exchanger. Energies 2020, 13, 6005. [CrossRef]

11. Cho, J.H.; Nam, Y.J. Analysis of the initial cost payback period on the open-loop geothermal system using two wells. Korean J. Air-Cond. Refrig. Eng. 2017, 29, 119-126.

12. ASHRAE Standard 90.1-2004; Energy Standard for Buildings Except Low-Rise Residential Buildings. 2004. Available online: https:/ / www.techstreet.com/ashrae/standards/ashrae-90-1-2019-i-p?gateway_code=ashrae\&product_id=2088527 (accessed on 2 December 2021).

13. ASHRAE Standard 90.2-2004; Energy-Efficient Design of Low-Rise Residential Buildings. 2004. Available online: https://www. techstreet.com/ashrae/standards/ashrae-90-2-2018?product_id=2030773 (accessed on 2 December 2021). 
14. Ministry of Land. Manual of Building Energy Saving Design, MLIT Criteria 2017-71. 2017. Available online: https://www.mlit. go.jp/jutakukentiku/jutakukentiku_house_tk4_000103.html (accessed on 2 December 2021).

15. ASHRAE Standard 55-2013; Thermal Environmental Conditions for Human Occupancy. 2013. Available online: https://www ashrae.org/technical-resources/bookstore/standard-55-thermal-environmental-conditions-for-human-occupancy (accessed on 2 December 2021).

16. New \& Renewable Energy Center, Korea Energy Agency. Unit Price per Renewable Energy Source, Criteria, 2012-2013; New \& Renewable Energy Center, Korea Energy Agency: Yongin-si, Korea, 2012.

17. Ministry of Land. Standard on Construction Estimate. 2017. Available online: https://www.codil.or.kr/helpdesk/read.do; jsessionid=1DrQsuDCUMEnnR8db1pAYUCraZx2QQHElPgb0mRlsOQ65aIhyuz9s2yl7fKC6Ga9.codil_servlet_engine1?bbsId= BBSMSTR_900000000202\&nttId=10908\&searchWrd= (accessed on 2 December 2021). 